\title{
Book Review: The Future University: Ideas and Possibilities
}

\author{
Edited by Ronald Barnett \\ New York, NY: Routledge, 2012. 233 pp. \\ ISBN:978-0-414-82425-5
}

In this edited volume, Ronald Barnett has assembled 20 colleagues to contribute to his long-standing interests in exploring the future university. Similar to his 2011 Being a University, this book in four parts goes back and forth between the "idea" of the university that has emerged over a thousand years of history and the possibilities that the contributors see going forward.

I learned from my professor, the late Rolland Paulston, to go directly to the end of a paper to check out its bibliography, just in case there's something there you haven't read yet. I also make a point of scanning indexes, and, judging from the subject index of this book, "knowledge," with all of its subheadings, is the topic referred to most often.

The strength of this collection is the long view most of the contributors take, beginning with Part 1 , on "emerging futures," with a chapter by the historian Sheldon Rothblatt. This chapter explores the possibilities for a recovery of liberal education, and one by Louise Morley asking, "whether the university of the future might also be seen as the university of the past" (26).

Part 2 of the book, on "global possibilities," includes chapters on Australia, China, Latin America, and South Africa.

Part 3 is devoted to "ideas of the university." The four chapters in Part 3 include one by Nicolas Standaert on the idea of the university as a set of networks and possibilities afforded by the spaces of the web, and one by Donncha Kavanagh on "The University as Fool" (I will return to this one at the end). A chapter by Gloria Dall'Alba explores the concepts of care, while the last chapter in this section distin- guishes two kinds of inquiry, "knowledge-inquiry" and "wisdom-inquiry," detailing how universities that seek and promote wisdom will help humanity create a better world (137).

Part 4 has five chapters devoted to "a university for society" rather than just "in society." Jon Nixon's chapter addresses the "common good," while Paul Standish suggests, in another chapter, that we move teaching and subject matter to the center of teacher/student interaction. The next chapter reproduces Jan Masschelein and Maarten Simons' article from 2010 on the university as a public issue. While a chapter by Berte van Wyk and Philip Higgs pleads for community research in Africa based on the local, another one explores the possibilities of new worldwide communication technologies. The next version of openness, which Michael A. Peters and his colleagues call "Openness 3.0," where "education is at the center of global society and human rights," will in turn, they argue, take us right to the verge of "knowledge socialism," which will replace presentday "knowledge capitalism" (198).

Nixon, in his chapter, points out how the modem university's role in inequality became acceptable because it was routinely presented as the consequence of meritocracy, justified as the inevitable consequence of a system supposedly based on equality of opportunity. This leaves universities in an awkward position. They are "the means by which highly influential sets of meritocratic criteria are routinely applied in the interests of social selection" (146). As such, not only do universities fall short of universal entitlement and a more democratic conception of higher education as a common good, 
but their aspirations to democracy are seriously compromised by the pursuit of efficiency, quality assurance, ranking on the various world-class rubrics and economic profitability. This chapter and the book as a whole predate the introduction of massive open online courses (MOOCs), which means that none of the chapters is able to take into account these very recent developments and their potential impact on the distribution of knowledge and education for all. Not that I think that MOOCs will topple the university as a global phenomenon, satisfy the ideal of knowledge as the common good, or help fulfill Dall'Alba's suggestion about moving from enhancing knowledge and skills to "interrogating possibilities for being" (117). However, I do think that any published volume about the future, even if it were science fiction, is always about the past and the present; the very idea of the future helps us draw lessons from the past and integrate the present.

The editor in his coda summarizes fifteen crosscutting themes in this volume, which helpfully brings the individual chapters together. One of these themes is the excess of economic and instrumental reason from which the university in our entrepreneurial age suffers. While this general observation is hardly new, the contributors here evoke ideas of responsibility, wisdom, care, networking, sustainability and openness, as ways of pulling the university back from the "knowledge capitalism" that closes off spaces for the traditional domains of teaching research and public services. In this connection, the editor comes back to his own attempt in Being a University, to develop an imaginative exposition of possible ideas of the university. He writes in the coda, "Imagination can help in going beyond the surface order of things, to discern possibilities that lie beneath" (203), and he observes that the chapters in this volume do examine such possibilities.

To conclude this review, I will go back to "The University as a Fool" by Kavanagh to illustrate what imagination can contribute to a contemporary analysis of the university as an institution. Interestingly, Kavanagh is a civil engineering graduate of University College Dublin where he is now a Professor of Information and Organisation in the School of Business. Holding an MSc in Civil Engineering from the University of Missouri and a PhD from Lancaster University Management School, he was a Fulbright Scholar at the University of San Diego in 2003. I mention here his accumulated academic capital because this book is very much about access to knowledge and its consequences. The editor's coda emphasizes the "combination of imagination and responsibility at play," and this combination is very much in evidence in the "playfoolness" (204) of Kavanagh's chapter.

One of the more literary exercises in the book, written by a trained engineer, this chapter invites us to apply an analysis of the Fool's role in mediaeval courts and elsewhere to our understanding of the past and imagination of a future university. Teaching in a business school-where, by Nixon's account, the language of technocrats, which now infests all institutions, including universities was first devised (149) - Kavanagh asks us to use the Fool's "many faces" to realign the university itself as it engages with different "sovereigns." Like the Fool, who does not just retell stories, the university's power comes from its ability "to sort things out," an ability which "will become even more important in a world overwhelmed by information chatter and trivia" (108). The university, like the Fool, personifies truth and reason; its "sorting practices and technologies are basic to how the University realizes its imagined community of academics, how it at once becomes an institution itself, and also how it maintains and sustains the semiotic nexus underpinning other institutions" (108).

Kavanagh finds the Fool an enduring trope to guide us through the nature of the university engagements not just in the past but also in the future, as the Fool reminds us that knowledge is always beyond even the wise. If we recognize that at best we can only know that there is much about which we are and can only be ignorant, then "the highest wisdom is perhaps to do nothing other than to play the Fool" (109), who is not expected to know anything. Such a role is also a source of great wisdom and this is perhaps why there is such a long tradition of the Wise Fool - a tradition that the university, as an enduring institution, might do well to associate itself with.

All in all, the contributors to this volume show 
how the university of the present and that of the future "cannot ratchet itself back" (6) in fulfilling its global potential and its social mission.

Reviewed by Esther E. Gottlieb

Ohio State University, USA 